Int. J. Dev. Biol. 49: 23-31(2005)

doi: $10.1387 / \mathrm{ijdb} .041905 \mathrm{jo}$

Original Article

\title{
Transforming growth factor beta2 promotes the formation of the mouse cochleovestibular ganglion in organ culture
}

\author{
JUNKO OKANO ${ }^{1,2}$, TOSHIYA TAKIGAWA ${ }^{1}$, KENJI SEKI ${ }^{1}$, SHIGEHIKO SUZUKI², KOHEI SHIOTA ${ }^{1,3}$ \\ and MAKOTO ISHIBASHI*,1 \\ ${ }^{1}$ Department of Anatomy and Developmental Biology, ${ }^{2}$ Department of Plastic and Reconstructive Surgery and ${ }^{3}$ Congenital Anomaly
} Research Center, Graduate School of Medicine, Kyoto University, Kyoto, Japan

\begin{abstract}
The inner ear structures are derived from the otic vesicle (OV) which is formed by thickening and invagination of the otic placode of the surface ectoderm. A number of neuroblasts, which arise from epithelial cells of the otic vesicle, delaminate and differentiate into neurons of the cochleovestibular ganglion (CVG). We have found that transforming growth factor- $\beta 2$ (Tgf $\beta 2$ ) was expressed in the otic epithelium at the OV stages between embryonic days (E) 9.5 and 11.5 and that anteroventrolateral localization of its expression in the OV overlapped with that of NeuroD, which is a marker of delaminating CVG precursors. The expression of TGF $\beta$ type I and type II receptors in the otic epithelium and the nuclear localization of phosphorylated-Smad2 in both the otic epithelium and CVG suggested that TGF $\beta 2$ signaling plays some roles in CVG formation. In order to examine the roles of TGF $\beta 2$ in differentiation of the inner ear, otic vesicle explants of E10.5 mouse embryos were treated in vitro with TGF $\beta 2$ or the TGF $\beta$ type I receptor kinase inhibitor, SB431542. Addition of TGF $\beta 2$ peptide to the culture led to enlargement of the CVG, while the inhibitor reduced its size. These findings strongly imply that TGF 22 contributes to the development of the CVG in mouse embryos.
\end{abstract}

KEY WORDS: TGF , epithelial-mesenchymal transformation, delamination, neuronal differentiation

\section{Introduction}

The mammalian ear is a delicate sensory organ for hearing and balance and is one of the most complex structures in the body. The inner ear primordium, the otic placode, first appears as a thickening of the surface ectoderm on which the neural plate neighbors. The otic placode invaginates to form the otic vesicle, which subsequently detaches from the surface ectoderm and form the inner ear structures such as the semicircular canals, vestibule and cochlea (Rossant, 2002).

The cochleovestibular ganglion (CVG) is formed by the cells which delaminate and migrate from the anteroventral portion of the otic vesicle (Carney et al., 1983) and the neural crest-derived cells (D'Amico-Martel and Noden, 1983; Rubel and Fritzsch, 2002). It has been shown that a large area of the anteroventrolateral part of the OV gives rise to the CVG neuroblasts in mice (Fritzsch, 2003) and these cells are among the first cell types to be specified during the early OV stages (Fekete and Wu, 2002; Hemond and Morest, 1991; Hossain et al., 2000). Recently, several genes have been identified that play crucial roles in development of the CVG. For example, the differentiation of the CVG depends on two basic helixloop-helix (bHLH) factors, Neurogenin1 (NGN1) and NeuroD. Ma et al. (1998) reported that the CVG was not formed in Ngn1 null mutants. In NeuroD mutant mice, migration of CVG precursors was compromised and there was considerable size reduction of the CVG (Liu et al., 2000; Kim et al., 2001). The roles of some growth factors have also been implicated in inner ear development. Double mutants of fibroblast growth factor (Fgf) 3 and Fgf10 lacked the CVG (Alvarez et al., 2003). It has also been shown that two neurotrophins, brain-derived neurotrophic factor (BDNF) and neurotrophin (NT)-3, are important for survival of the neuroblasts since the size of the CVG was decreased in single and double homozygous mutant mice (Ernfors etal., 1995; Bianchi etal., 1996; Farinal et al., 1994; Jones et al., 1994). Further, insulin-like growth

Abbreviations used in this paper: BDNF, brain derived neurotrophic factor; BMP, bone morphogenetic protein; CVG, cochleovestibular ganglion; E, embryonic day; Fgf, fibroblast growth factor; IGF, insulin-like growth factor; NGN, neurogenin; NT, neurotrophin; OV, otic vesicle; TGF, transforming growth factor.

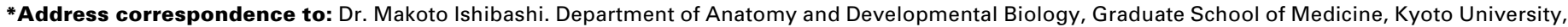
Yoshida Sakyo-ku, Kyoto 606-8501, Japan. Fax: +81-75-751-7529. e-mail: ishibash@anat1.med.kyoto-u.ac.jp web: http://www.anat1.med.kyoto-u.ac.jp/index-j.htm
} 
E9.5
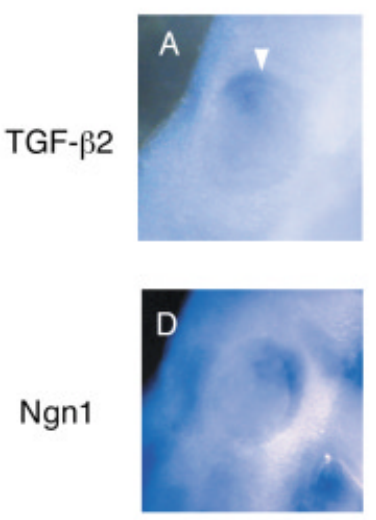

Ngn1
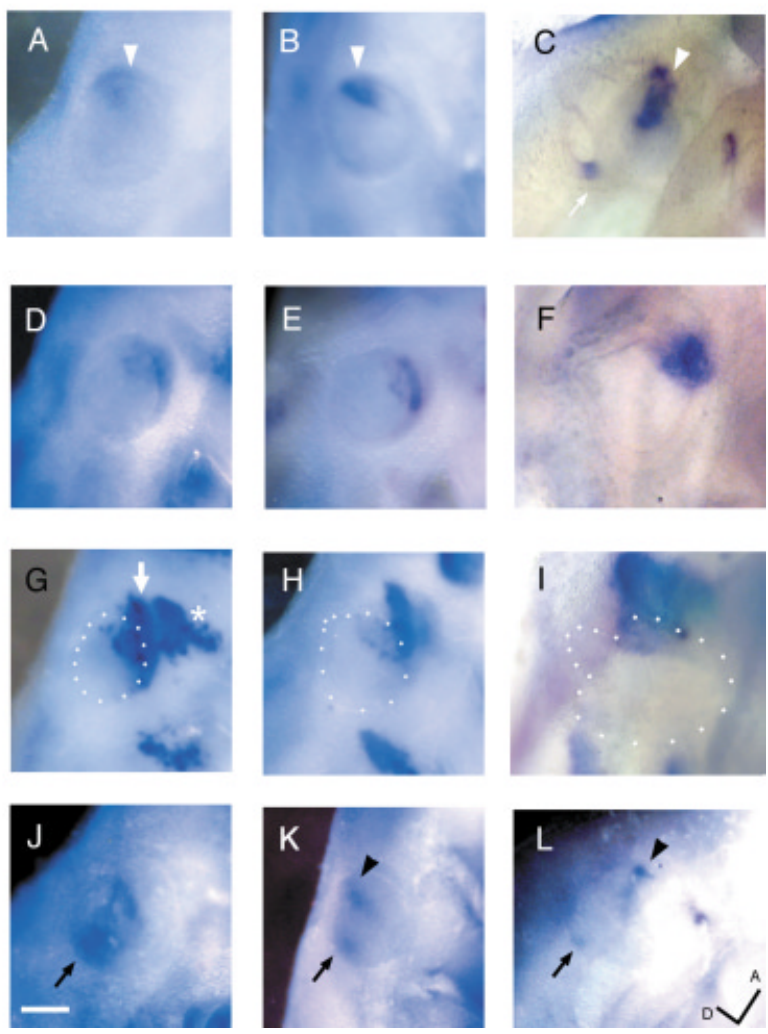

Fig. 1. Expression patterns of Tgf $\beta 2$, Neurogenin 1(Ngn1), NeuroD and Bmp4 in the mouse developing OV. Tgf $\beta 2$ expression was detected in the anterior wall (arrowhead) of the otic vesicle at E9.5 (A) and became more intense at E10.0 (B). At E10.5, Tgf 32 transcripts were also detected in the posterior part of the vesicle as well as in the anterior wall (C). Neurogenin 1 was also expressed in the anterior region between E9.5 and 10.5 (D,E,F). Note that its expression domain partially overlapped with that of Tgf $\beta 2$. NeuroD was expressed in the same region as Neurogenin 1 in the epithelium as well as in the neuronal precursors of the CVG between E9.5 and $E 10.5(\mathbf{G}, \mathbf{H}, \mathbf{I})$. Bmp4 was expressed in the posterior wall (arrow) of the OV at E9.5 (J), E10.0 (K) and E10.5 (L) and also in the anterior wall (arrowhead) at E10.0 (K) and E10.5 (L). Dotted circles indicate the contour of the OV. The thick arrow and the asterisk in (G) show the developing CVG and the facial ganglion, respectively. Direction is indicated in $(L)$ for all panels (A, anterior; $D$, dorsal). Scale bar, $100 \mu \mathrm{m}$.

factor-1 (IGF-1) has been suggested to be necessary for CVG differentiation (Camarero et al., 2001; Camarero et al., 2002; Camarero et al., 2003).

Transforming growth factor- $\beta$ (TGF $\beta$ ) is a secreted peptide which promotes cell survival during the development of the central and peripheral nervous systems (Sporn et al., 1987; McFarlane and Cooper, 1993). Three isoforms of TGF $\beta$ (TGF $\beta 1,2$ and 3) show distinct spatial and temporal expression patterns in mouse embryos, suggesting that they play various roles during embryogenesis (Flanders et al., 1991; Johnson et al., 1993). Blottner et al. (1996) reported that implantation of gelform soaked with TGF $\beta 2$ rescued all the injured neurons of the preganglionic sympathetic neurons in the spinal cord, though the mechanisms remain to be clarified. It has been shown that TGF $\beta 1$ is a potent survival factor for motor neurons of rat embryos (Martinou et al.,
1990) and it has also been shown that the TGF $\beta 2 / 3$ promote the survival of midbrain dopaminergic neurons (Poulsen et al., 1994). Recently, Farkas et al. (2003) showed that both TGF $\beta 2$ and TGF $\beta 3$ are required for induction of midbrain dopaminergic neurons as well. They showed that TGF $\beta 2 / 3$ were expressed in the notochord and floor plate and that neutralization of TGF $\beta 2 / 3$ abolished induction of dopaminergic neurons in rat primary cultures and E2 chick embryos.

Although the pattern of TgfB2 expression during inner ear development has been reported previously (Pelton et al., 1990; Millan et al., 1991; Schmid et al., 1991), their description was not conferred at the OV stages. In this study, we examined the

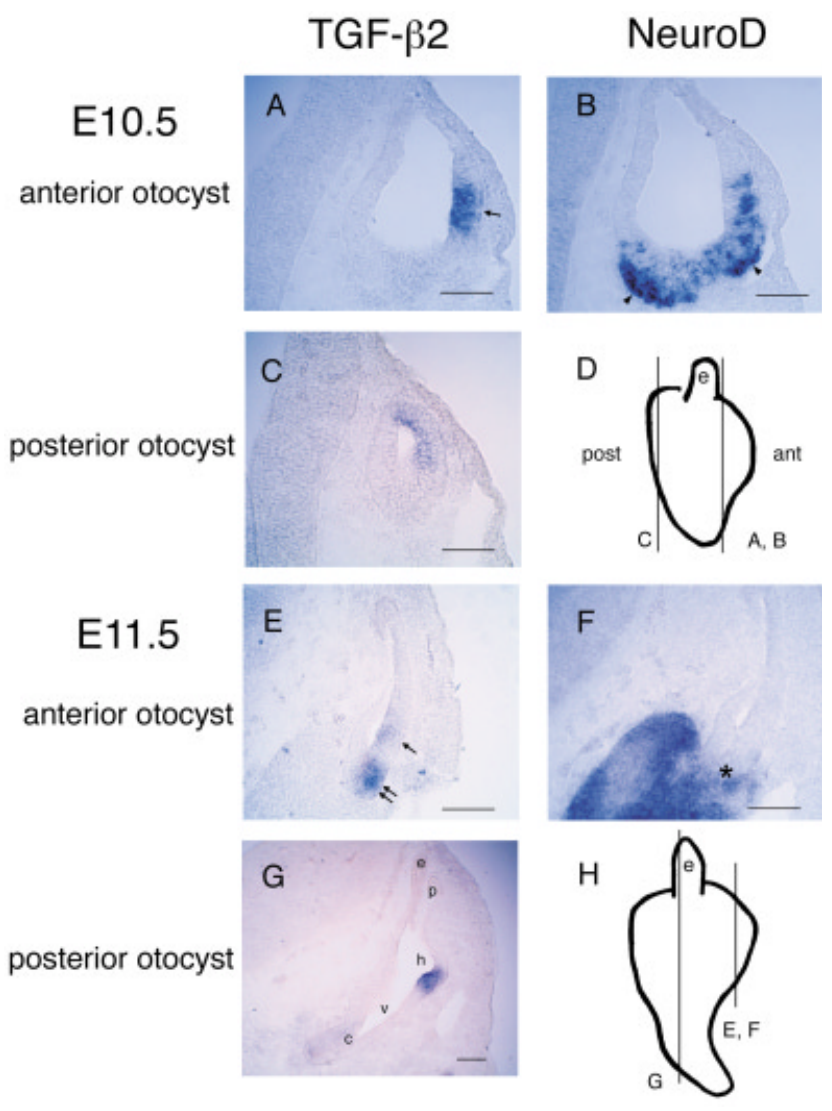

Fig. 2. Detailed expression patterns of Tgf $\beta 2$ and NeuroD by section RNA in situ hybridization. Sections of the anterior $(A, B, E, F)$ and posterior $(C, G)$ parts of the OV were stained with $\operatorname{Tgf} \beta 2(A, C, E, G)$ and NeuroD $(B, F)$ probes. $(D)$ and $(H)$ indicate the plane of each section. At E10.5, Tgf $\beta 2$ was detected in the ventrolateral region of the anterior OV(A) (see arrow), while NeuroD was expressed in both ventrolateral and ventral regions (B) (see arrowheads). NeuroD was also detected in the delaminated precursors (B). In the posterior OV, Tgf $\beta 2$ was observed in the dorsolateral region where NeuroD was not expressed (C). At E11.5, Tgf $\beta 2$ was expressed in the ventral region ( $(\mathbf{E})$, double arrow) in addition to the ventrolateral region ( $E$, arrow) of the anterior OV. On the other hand, NeuroD expression was observed in a small number of the ventral epithelial cells of the anterior OV (F) (see asterisk) and in the delaminated CVG cells. In the posterior OV, Tgfß2 was expressed around the boundary between the horizontal semicircular canal and the vestibule. ant, anterior; c, cochlear duct; e, endolymphatic duct and sac; $h$, horizontal semicircular canal; $p$, posterior semicircular canal; post, posterior; $v$, vestibule. In all panels dorsal is towards the top. In $A, B, C, E, F, G$, lateral is towards the right. Scale bar, $100 \mu \mathrm{m}$. 
expression patterns of Tgfß2 in the developing OV of mouse embryos by RNA in situ hybridization. We also treated cultured mouse embryonic OVs with TGF $\beta 2$ or TGF $\beta$ type I receptor kinase inhibitor and analyzed their effects on the developing OV. Our data suggest that TGF $\beta 2$ may contribute to inner ear development, especially to the formation of the CVG.

\section{Results}

The expression of Tgf $\beta 2$ overlaps that of Neurogenin and NeuroD in the early otic vesicle

TgfB2 expression in the otic epithelium was examined at OV stages (E9.5-E11.5) by RNA in situ hybridization. At E8.5-9, Tgfß2 expression was not detected in the otic placode or pit. At E9.5, when the otic vesicle formed, Tgf 2 transcripts were detected in the anteroventrolateral region of the otic vesicle (Fig. 1A). At E10.0 and $E 10.5, \operatorname{Tg} f 32$ was more intensely expressed than at $E 9.5$ in the anteroventrolateral wall and also came to be detectable in the posterodorsolateral wall (Fig. 1 B,C). Transverse sections revealed that its expression was confined to the epithelium of the otic vesicle, but not in the surrounding mesenchyme (Fig. $2 \mathrm{~A}, \mathrm{C}$ ).

The neuronal precursors for the CVG delaminate from the anteroventral wall of the OV between E9.5 and E11.5 with its peak at E10.5 (Carney et al., 1983). We compared the expression patterns of TgfB2 with those of the neural bHLH genes $\mathrm{Ngn} 1$ and NeuroD, which have essential roles in CVG development (Ma et al., 1998; Liu et al., 2000). Ngn1 expression was first detected in the anteroventrolateral region of the otic epithelium at E9.0 when the otic placode began to invaginate (Raft et al., 2004). At E9.5 and E10.0, Ngn1 was expressed in the anteroventrolateral wall of the $\mathrm{OV}$ and its expression domain partially overlapped with that of Tgfß2 (compare Fig. 1 A,B and D,E).

NeuroD was first faintly expressed in the same region as $\mathrm{Ngn} 1$ at E9.0 (Liu et al., 2000; Raft et al., 2004). Its expression became intense in the delaminating precursors and CVG cells by E9.5 (Fig. $1 \mathrm{G})$. The epithelial domains of $\mathrm{Ngn1}$ and NeuroD expression overlapped with each other up to E11.5 (Fig. 1 D-I). The expression domain of $N e u r o D$ in the otic vesicle also partially overlapped with that of TgfB2 (compare Fig. $1 \mathrm{~A}, \mathrm{~B}, \mathrm{C}$ and $\mathrm{G}, \mathrm{H}, \mathrm{I}$ ). To analyze their expression patterns in detail, we performed section RNA in situ hybridization. At E10.5, both TgfB2 and NeuroD transcripts were found in the anteroventrolateral regions of the otic vesicle (Fig. 2 $A, B)$, although their expression patterns were not exactly identical. Tgf 2 was expressed more intensely in the luminal and intermediate layers than in the outer layers of the otic epithelium (Fig. 2A), whereas NeuroD was more intensely expressed in the otic

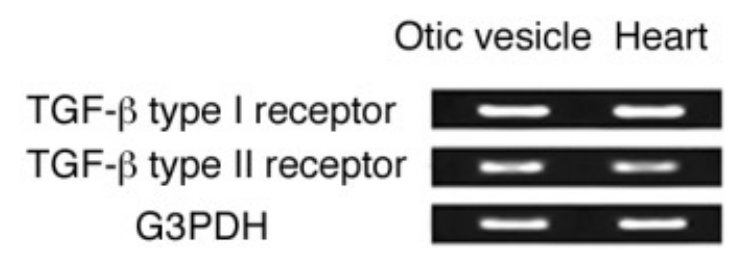

Fig. 3. Expression of TGF $\beta$ type l and II receptors in the developing OV. One $\mu \mathrm{g}$ of RNA extracted from E10.5 otic vesicles was subjected to RT$P C R$. The heart was used as a positive control. Robust expression of both receptors was observed in the otic vesicle $(27$ cycles). Three independent experiments were performed and the representative data are shown.

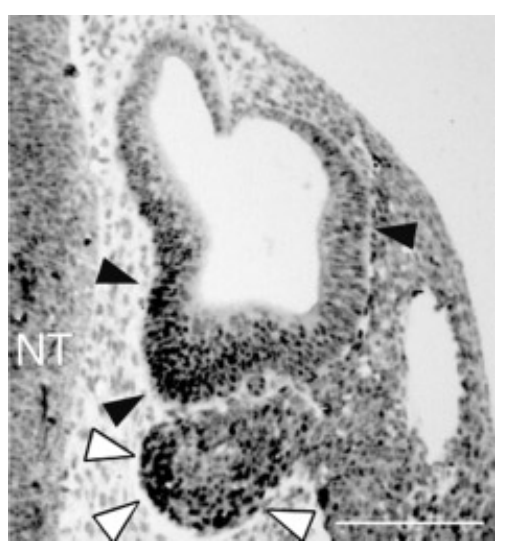

Fig. 4. Immunohistochemistry of phosphorylated Smad2 (P-Smad2) at E10.5. Intense nuclear staining of P-Smad2 was detected in the anteroventral regions of the otic vesicle (arrowheads) and CVG (open arrowheads). Note that the staining was more intense in the outer parts of both structures than in the inner parts. A number of cells were positive for nuclear P-Smad2 in the adjacent neural tube (NT). Scale bar, $100 \mu \mathrm{m}$.

epithelial cells near the mesenchyme (Fig. 2B). Tgfß2 expression was also observed in the posterodorsolateral otic epithelium (Fig. 2C) where NeuroD was not detectable (data not shown). At E11.5, when the endolymphatic duct became more overt and the cochlear anlage expanded ventrally, Tgf 2 expression still remained on the anteroventral wall of the OV, although the expression domain slightly shifted to the outer layers in the ventral region (Fig. 2E). NeuroD was also detected in a few cells of the same domain (Fig. $2 \mathrm{~F})$. Robust expression of TgfB2 was also detected in the posteroventrolateral wall at E11.5 (Fig. 2G).

Bone morphogenetic protein (BMP) 4 is another member of TGF $\beta$ superfamily which has been shown to be expressed in the developing OV of both chick and mice (Wu and Oh, 1996; Morsli et al., 1998; Raft et al., 2004). To further clarify the expression domain of TgfB2, we compared its expression with that of Bmp4. At E9.5, Bmp4 was expressed in the posterodorsal wall of the OV (Fig. 1J). At E10 and later, it was also detectable as a streak domain in the anterior wall (Fig. $1 \mathrm{~K}, \mathrm{~L}$ ). These two loci correspond to the anterior and posterior cristae (Wu et al., 1996). The expression domains of $T g f B 2$ and Bmp4 seemed to be very close to each other but not to overlap.

In summary, Tgf 2 transcripts were localized in the antreoventrolateral wall and in the posterolateral region of the otic vesicle at E9.5-11.5. Tgf 2 expression overlapped with that of NeuroD in the anteroventolateral compartment.

\section{TGF $\beta$ type I and type II receptors and phosphorylated Smad2 are present in the developing $\mathrm{OV}$}

To examine whether TGF $\beta$ type / and type // receptors are expressed in the developing OV, we used RNA in situ hybridization. Since their expression levels were too low to be detected with digoxigenin-labeled probes, we performed RT-PCR, which is much more sensitive than RNA in situ hybridization, using OVs of E10.5 (35-39 somites) embryos. The embryonic heart tissue, which expresses those receptors most strongly at this stage (Mariano et al., 1998), was used as a positive control. The OVs showed comparable expression levels of both TGF $\beta$ type / and type // receptors to the embryonic hearts (Fig. 3 ). 

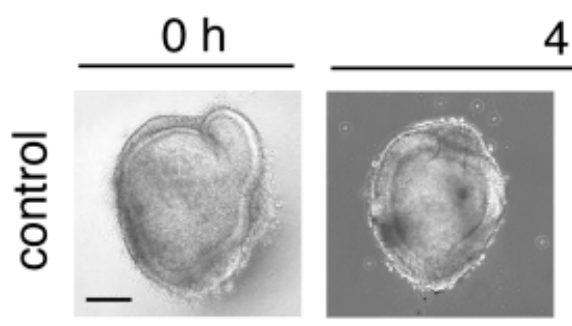

$4 \mathrm{~h}$
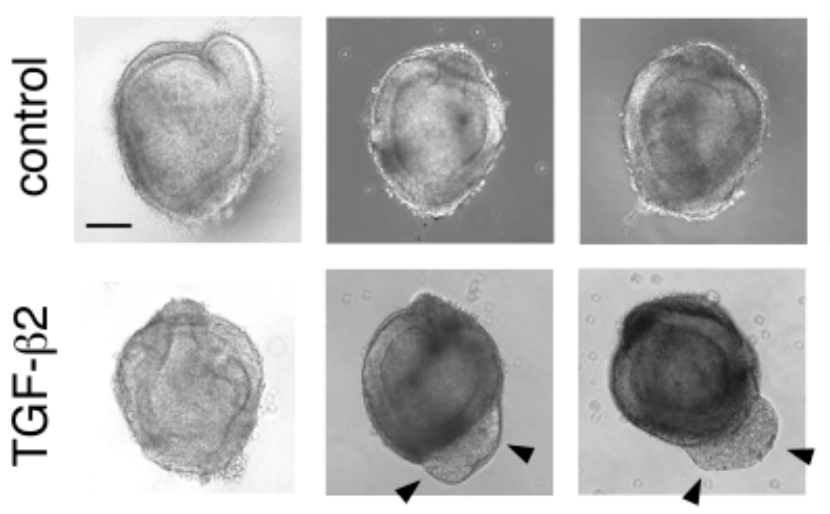

Next, to confirm that TGF $\beta$ signaling is actually active in the OV, we carried out an immunohistochemical study using an antiphosphorylated Smad2 antibody. Phosphorylation of Ser465 and Ser467 of Smad2 is required for the Smad2/Smad4 complex formation and TGF $\beta$ signal transduction (Nakao et al., 1997; Abodollah et al., 1997; Souchelnytskyi et al., 1997; de Caestecker et al., 1998). Nuclear localization of phosphorylated Smad2 indicates that TGF $\beta$ signaling is conveyed to the nucleus in the cells (Heldin etal., 1997; Massague et al., 1998; Massague and Wotton, 2000). Intense nuclear staining was observed in the anteroventolateral wall of the otic epithelium and the outer cells of the CVG (Fig. 4), indicating that TGF $\beta$ may signal in these regions. There were phosphorylated Smad2-positive cells in the neural tube (Fig. 4) as previously reported by Farkas et al. (2003).

\section{TGF $\beta 2$ increases the size of the cochleovestibular ganglion in cultured otic vesicles}

Since TgfB2 was expressed in the anteroventrolateral wall of the OV, we assumed that TGF $\beta 2$ might play some role in CVG development. To test this hypothesis, we cultured the otic vesicles of E10.5 mouse embryos in which CVG precursors delaminate most actively from the otic epithelium (Carney et al., 1983) and treated them with TGF $\beta 2$. Within 16 hours in culture a mass of cells migrated out of the anteroventrolateral region of the OV and formed a CVG-like structure (Fig. 5). Many of the cells forming this structure were positive for Tuj1, an early neuronal marker (Fig. 6). Our observation along with the study of Camarero etal. (2003) suggests that this structure was likely a newly-formed CVG in the culture.

To examine the effects of TGF $\beta 2$ on the differentiation of OVs, we treated cultured OVs with recombinant TGF $\beta 2$ protein. With TGF $\beta 2,6$ of 14 OV explants (42.9\%) produced the CVG after 4 hours incubation whereas no CVG was formed in the control cultures (Fig. 5; Table 1). Likewise, when the explants were incubated for 6 hours, 15 of 24 cultured vesicles $(62.5 \%)$ produced the CVG with TGF $\beta 2$ whereas only 4 of $25(16.0 \%)$ formed without TGF $\beta 2$ (Table 1). Moreover, the size of the CVG was increased with TGF $\beta 2$ (compare the top and bottom panels in Figs. 5,6) when compared to the control samples (Figs. 5,6), suggesting that TGF $\beta 2$ accelerates CVG formation.

To quantitate the effects of TGF $\beta 2$ on CVG development the area of the CVG on photographs was measured using the technique of Camarero et al. (2003). The area of the CVG treated with TGF $\beta 2$ was increased by 1.4 -fold $(P<0.001$, Fig. $7 A)$. We also

\section{$16 \mathrm{~h}$}
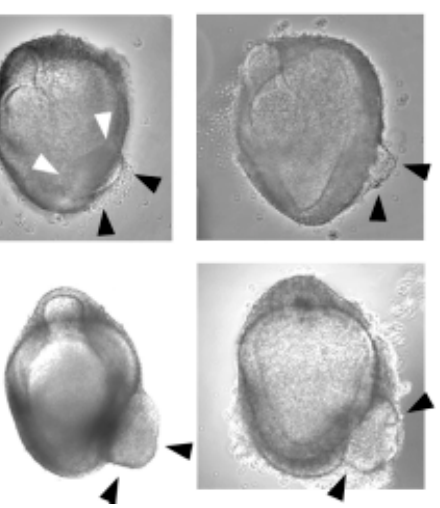

Fig. 5. Organ culture of otic vesicles from E10.5 embryos. Top and bottom panels show controls and the culture treated with TGF $\beta 2(10 \mathrm{ng} / \mathrm{ml})$, respectively. Incubation periods are indicated at the top. $0 \mathrm{~h}$ represents the beginning of the culture. The already formed CVG was removed from the explants before culture. After 4 hours, there was no CVG in controls, while several vesicles already produced the CVG (arrowheads) when treated with TGF 32 protein (see Table 1). After $16 \mathrm{~h}$, larger CVGs (arrowheads) were formed with TGF $\beta 2$ than in controls. Scale bar, $100 \mu \mathrm{m}$.

measured the area of the remaining epithelium of the OV and found that the average area of the treated group was significantly smaller than that of the control group $(\mathrm{P}<0.001$, Fig. 7B), suggesting that TGF $\beta 2$ promotes CVG formation at the expense of the epithelial cells of the OV.

To determine whether TGF $\beta 2$ increases the number of CVG precursors or cell proliferation of neuroblasts, we performed immunostaining with anti-phosphorylated histone3, a proliferation marker. There was no clear difference between the control and TGF $\beta 2$-treated tissues (data not shown), suggesting that TGF $\beta 2$ increases the number of CVG precursors instead of promoting cell proliferation.

Next, we treated OVs with the TGF $\beta$ type I receptor kinase

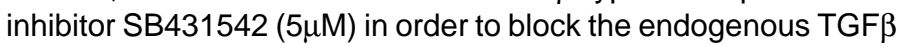
signaling. The area of the CVG treated with SB431542 was

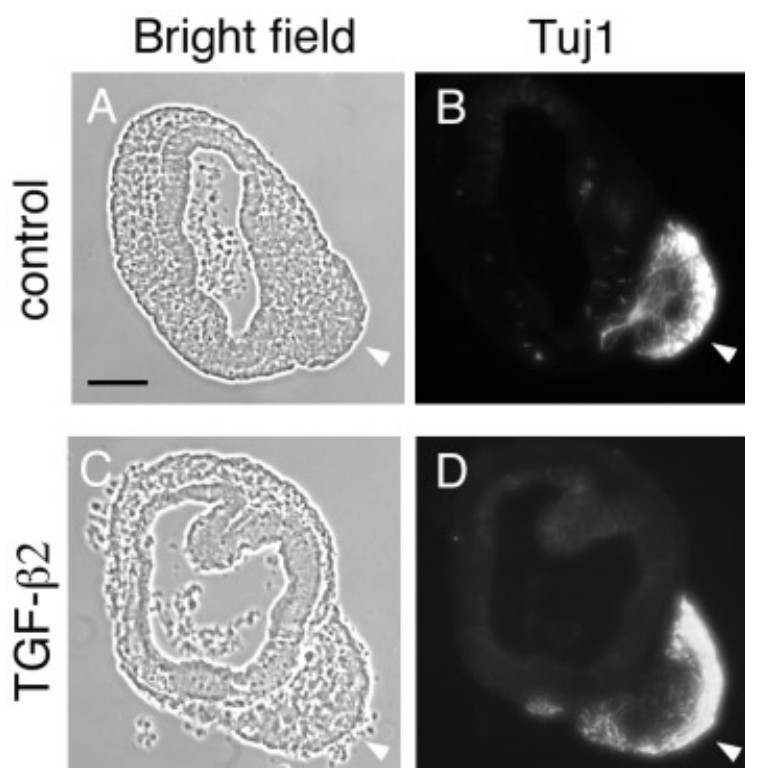

Fig. 6. Tuj1 immunohistochemistry of OV culture. (A,B) Controls. (C,D) Explants treated with TGF 32 . After 16 hours, OV explants were harvested and subjected to immunostaining for Tuj1, an early neuronal marker. (A,C) Phase contrast photographs. Tuj1 immunoreactivity was detected in the CVG (arrowhead) in both control and TGF $\beta$-positive cultures. Note that the $C V G$ in TGF $\beta 2$-treated culture $(C, D)$ is larger than in the control culture $(A, B)$. Scale bar, $100 \mu \mathrm{m}$. 
significantly reduced when compared to the control vesicles $(\mathrm{P}<$ 0.01, Fig. 7C).

\section{Slug expression is downregulated in the TGF $\beta 2$-treated OV}

It was previously reported that TGF $\beta 2$ upregulates the expression of Slug, a member of the Snail family that is involved in delamination of endothelial cells in the embryonic heart (Romano and Runyan, 2000). We have found that Slug was expressed in the developing OV of the mouse embryo (unpublished data). Since the delamination of CVG precursors from the $\mathrm{OV}$ is a similar phenomenon to epithelial-mesenchymal transformation (EMT), we examined by semi-quantitative RT-PCR whether the expression of S/ug is affected with TGF $\beta 2$ in the OV. mRNA was extracted from the whole culture including both the vesicle and CVG after various incubation intervals (Fig. 8). The intensity of the PCR bands was measured and normalized by that of EF1 products. The relative intensity of the bands from TGF $\beta 2$-treated OVs to the control was 0.624 (1.5h), 0.409 (2h), 0.569 (4h), 0.631 (6h) and 0.886 (16h), indicating that S/ug mRNA was substantially reduced in culture treated with TGF $\beta 2$.

\section{Discussion}

In this study we found that $T g f \beta 2$ is expressed in the epithelium of the mouse OV in a distinct pattern. TGF $\beta$ type / and type // receptors and phosphorylated Smad2 were also detected in the otic vesicle, suggesting that TGF $\beta$ signaling is underway during inner ear development.

Brigande et al. (2000) proposed that the spherical OV can be divided into eight compartments by the anteriorposterior, dorsal-ventral and medial-lateral boundaries and that different parts of the inner ear are derived from different compartments. Alsina et al. (2004) designated the anteroventral domain as "proneural sensory territory" (proNS) because proneural and neurogenic genes, including Neurogenin 1 and NeuroD, are expressed in this domain. They observed that CVG precursors delaminated around the boundary between proNS and its posterior region.

During inner ear development, numerous otic epithelial cells delaminate from the anteroventrolateral region, a part of the proNS, to form the CVG. This delamination is similar to EMT as seen in neural crest cell differentiation in terms of the loss of epithelial characters, migration and neuronal differentiation. In addition, TGF $\beta$ signaling is known to be involved in neural crest cell development. TGF $\beta$ s have been shown to induce EMT during cardiac, palatal and hair follicle development and in cutaneous wound repair (Sanford et al., 1997; Sun et al., 1998; Romano and Runyan, 2000; Camenisch et al., 2002). During heart development TGF $\beta 2$ promotes EMT of the endothelial cells to produce the endocardial cushions (Romano and Runyan, 1999). It has also been reported that cytokeratin was downregulated when the otic epithelial cells delaminate (Lawoko-Kerali et al., 2004). When the mouse mammary epithelial cell line was treated with TGF $\beta 1$ or TGF $\beta 2$, its characteristic epithelial pattern was disrupted and the regular meshwork pattern of cytokeratin was disturbed in these cells (Miettinen et al., 1994).
TABLE 1

\section{FORMATION OF CVG IN EXPLANTS CULTURED WITH TGFB2}

\begin{tabular}{lcccc} 
Interval & TGFß2 & Total explants & CVG(+) explants & $(\%)$ CVG(-) explants(\%) \\
\hline 4 hours & - & 14 & $0(0.0)$ & $14(100)$ \\
& + & 14 & $6(42.9)^{*}$ & $8(57.1)$ \\
\multirow{2}{*}{6 hours } & - & 25 & $4(16.0)$ & $21(84.0)$ \\
& + & 24 & $15(62.5)^{\star}$ & $9(37.5)$ \\
\hline
\end{tabular}

*Significantly different from controls by Chi-square test $(\mathrm{P}<0.01)$

In our present study Tgf 2 showed an intense and dynamic expression pattern in the developing OV. It was expressed in the anteroventrolateral otic epithelium in the proNS compartment at E9.5 and then also detected in the posterodorsolateral wall by E10.5. At E11.5, the latter Tgf 2 expression domain shifted to the posteroventrolateral wall. It was noteworthy that the expression domain of TgfB2, at least partially, overlapped with those of nuclear phosphorylated Smad2 and NeuroD. NeuroD is a marker of delaminating CVG precursors in the mouse OV (Ma etal., 1998; Raft et al., 2004). This result suggests that TGF $\beta 2$ is likely to signal to NeuroD -positive cells in paracrine and/or autocrine fashions.

NGN1 is another neurogenic bHLH transcription factor which is expressed in the same population of the otic epithelium. Both Ngn1 and NeuroD knockouts showed CVG defects (Ma et al.,

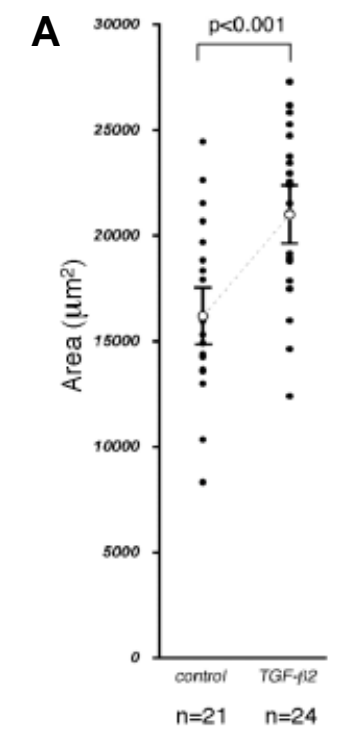

Average $(\mu \mathrm{m})$ ): $16194 \pm 893 \quad 21008 \pm 863$ CVGITGFP2
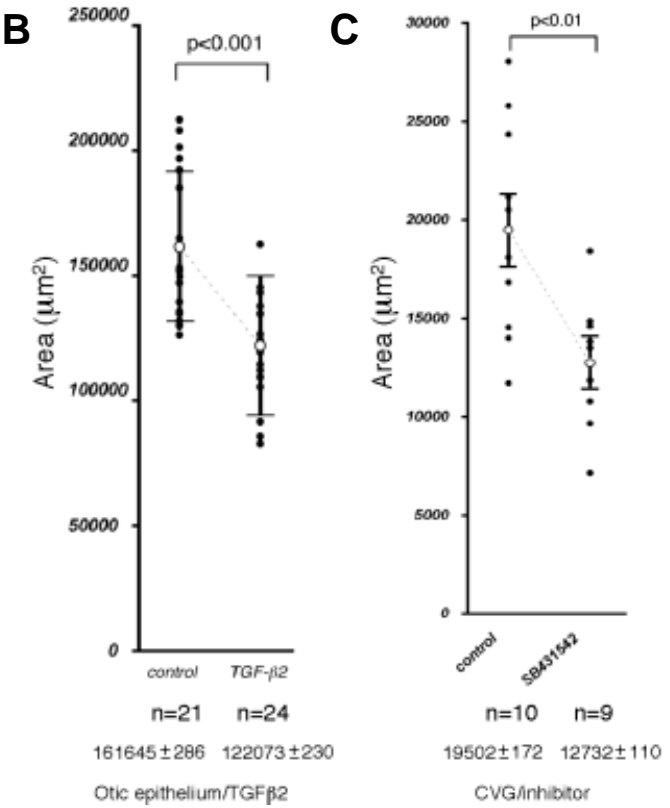

Fig. 7. The size of the CVG and otic epithelium in culture. The areas of the CVG (A) and otic epithelium (B) were estimated on microphotographs by NIH Image program (http://rsb.info.nih.gov/nih-image/). The vertical axis indicates areas $\left(\mu \mathrm{m}^{2}\right)$. Dots represent individual values. Open circles indicate the average areas with standard errors. The total numbers of the explants (n) and the average areas are indicated at the bottom of each panel. The area of the CVG with TGF 32 was significantly larger than control $(P<0.001)$. In contrast, the area of the epithelium with TGF $\beta 2$ was significantly smaller than control $(P<0.001)$. (C) A TGF $\beta$ signaling inhibitor, SB431542 $(5 \mu \mathrm{M})$, significantly decreased the size of the CVG $(P<0.01)$. 


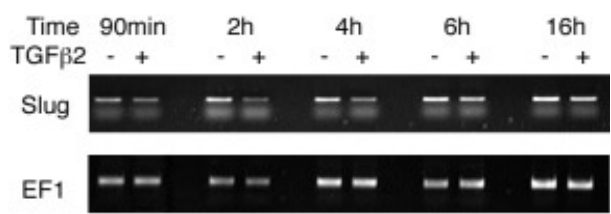

Fig. 8. Downregulation of Slug with TGFß2 in culture To examine whether Slug is involved in size increase of the CVG, Slug expression levels were analyzed by semi-quantitative RT-PCR. Otic vesicle explants from E10.5 embryos were cultured with or without TGF $\beta 2$ for 1.5, 2, 4, 6 and 16 hours. After culture, mRNA was extracted from the whole culture including both the otic epithelium and CVG and subjected to RT-PCR with Slug primers (top panel). At each time point, the left lane is control (-) and the right lane is with TGF $\beta 2(+)$. Slug was substantially downregulated with TGFB2 at 2 hours. The extent of downregulation was less at other time points. Elongation factor 1 primers were used as a control (bottom panel).

1998; Liu et al., 2000; Kim et al., 2001) and downregulation of NeuroD in Ngn1 mutants implied the requirement of Ngn1 for NeuroD expression. According to Sun et al. (2001), Smad1, a mediator of TGF $\beta$ signaling, forms a transcriptional complex with NGN1. Therefore, it may be interesting to determine whether TGF $\beta 2$ signals to NeuroD-positive cells through Ngn1.

The Ngn1 and NeuroD expression domains seemed to be restricted to the anterior compartment by TBX1. TbX1 is one of Tbox genes and is expressed in the developing OV (Raft et al., 2004). Its expression showed a posterior-anterior gradient first at E9.5, suggesting that TBX1 specifies the posterior compartment of the OV. Indeed, the $\mathrm{Ngn} 1$ and NeuroD expression domains expanded in $T b \times 1$ knockouts, leading to the duplication of the CVG rudiment (Raft et al., 2004). Therefore, it is intriguing to examine whether Tbx 1 expression is downregulated by TGF $\beta 2$ treatment.

It has been reported that Bmp4 is also expressed in the developing OV. Wu and Oh (1996) suggested that BMP4 plays important roles in specification of sensory primordia of the otic epithelium. The previous and present studies demonstrated that the expression domains of Bmp4 and TgfB2 were very close to each other but not overlapped in the anterior and posterior parts of the OV. Since addition of TGF $\beta 2$ to OV culture led to increased size of the CVG (a mass of sensory neurons), it may be possible that BMP4 and TGF $\beta 2$ cooperatively specify sensory neuron precursors in the developing OV.

We showed that exogenous TGF $\beta 2$ increases the size of the CVG and that inhibition of the endogenous signaling suppresses the CVG formation. The data suggest that TGF $\beta 2$ may have increased the number of cells which are to become delaminating CVG precursors and/or their proliferation during CVG development. Although TGF $\beta$ has been shown to stimulate the proliferation of spiral ganglion cells (Hansen et al., 2001), we observed that the size of otic vesicles treated with TGF $\beta 2$ was significantly reduced after 16 hours in culture (Fig. 6C) while the size of the CVG was increased. It is possible that more cells are specified as delaminating CVG precursors with exogenous TGF $\beta 2$ at the expense of the epithelial cells, though the possibility cannot be excluded that TGF $\beta 2$ accelerates proliferation of the neuronal precursors while it decreases proliferation of non-neuronal precursors.

Recently Lawoko-Kerali etal. (2004) reported that the NeuroDpositive domain of the OV might be further divided into two regions. The medial region was positive for GATA3, a zinc finger transcription factor and thought to produce the cochlear part of the CVG. The GATA3-negative region was thought to produce the vestibular part. Although these two parts of the ganglion are morphologically separated in vivo, we cannot distinguish the two parts in organ culture. Still, it is intriguing to determine which part of the CVG is increased in size after TGF $\beta 2$ treatment by examining GATA3 expression.

In spite of defects in other parts of the inner ear (Sanford et al., 1997), the CVG phenotype in Tgfß2 mutants has not been reported to date. The inner ear phenotypes of the mutants included the defects of the spiral limbus in the basal cochlear turn and Rosenthal's canal. The primary auditory neurons were normally formed in the mutants, but the interdental cells overlying the spiral limbus were undifferentiated. It should be noted that such anomalies of the inner ear in Tgf32 mutants were restricted to nonsensory areas, which is not consistent with our in vitro data. It is likely that the phenotype of the sensory area was rescued in vivo by other members of the Tgf $\beta$ family while that of the nonsensory area was not. This posterior domain did not express the proneural gene NeuroD. According to Fekete and $\mathrm{Wu}$ (2002), the nonsensory area of the cochlear duct arises from the posteroventrolateral compartment. Therefore, the inner ear defects in null mutants may be related to the posterior domain of Tgf 32 expression.

It is not known whether TgfB $1 / 3$ rescue the CVG phenotype though they are expressed in or near the OV. TGF $\beta 1$ begins to be immunolabeled in the periotic mesenchymal cells surrounding the developing OV, which form the capsule of the inner ear (Frenz et al. 1992). Other factors might also compensate the TgfB2 function, since TGF $\beta 2$ works synergistically with other factors such as BDNF and glial cell line-derived neutrophic factor (GDNF) in the nervous system (Sometani et al., 2001; Krieglstein et al., 2002; Sometani et al., 2002).

Slug, a zinc finger-type transcription factor, has been reported to play a crucial role in EMT during neural crest cell differentiation (Sefton et al., 1998; del Barrio and Nieto, 2002). Romano and Runyan (2000) suggested that S/ug is an essential target of TGF $\beta 2$ signaling during EMT of endocardial cushion formation. Delamination of CVG precursors from the otic epithelium is similar to EMT in terms of loss of epithelial character. However, in our RTPCR study, S/ug mRNA was downregulated when cultured OVs were treated with TGF $\beta 2$, which is not consistent with the previous report (Romano and Runyan, 2000). One possible explanation for the discrepancy between the studies is as follows: Slug functions in the epithelial cells to cause transformation and is quickly downregulated in the transformed cells. Although addition of TGF $\beta 2$ led to increase of CVG cells and decrease of epithelial cells, the analysis of the culture explants showed that S/ug mRNA was seemingly downregulated in our experiments. Another possibility is that the delamination of CVG precursors is an unrelated phenomenon to EMT. Delaminated precursors do not seem to go through mesenchymal cell stages. It is rather similar to migration of neuroblasts from the ventricular zone to the mantle zone in the developing neural tube. Therefore, it is possible that Slug plays a different role from that in neural crest development and is differently regulated by TGF $\beta 2$ signaling in the OV. Further study is required to elucidate how TGF $\beta 2$ regulates S/ug expression and transformation of the otic epithelial cells and whether Slug is involved in transformation of the otic epithelial cells. 


\section{Materials and Methods}

\section{RNA in situ hybridaization}

Embryos were collected between E9.0 and E11.5. The noon on the day of finding a vaginal plug was designated as E0.5. Whole mount and section RNA in situ hybridization was carried out as previously described (Wilkinson, 1992; Ishii et al., 1997). Embryos were fixed overnight in 4\% paraformaldehyde at $4{ }^{\circ} \mathrm{C}$, rinsed in PBS and dehydrated in $25 \%$ sucrose for section or in methanol for whole mount. Transverse sections $(20 \mu \mathrm{m})$ were mounted on APS-coated slides (Matsunami, Japan). Murine Tgf 2 probe (Pelton et al., 1991) was kindly provided by Dr. Moses. NeuroD (Lee et al. 1995) and Ngn1 probes (Cau et al.1997) were gifts from Dr. Kageyama. Digoxigeninlabeled sense and antisense probes were synthesized by digoxigenin RNA labeling kit (Roche Diagnostics Corporation, Indianapolis, IN, USA). Whole mount embryos were cleared in $80 \%$ glycerol.

\section{Immnohistochemistry}

Embryos at E10.5 were fixed for $1 \mathrm{~h}$ in $4 \%$ paraformaldehyde at $4^{\circ} \mathrm{C}$, followed by routine procedures for embedding in paraffin. Transverse sections $(6 \mu \mathrm{m})$ were mounted in a serial order on slides. Sections were treated in $10 \mathrm{mM}$ sodium citrate buffer at $95^{\circ} \mathrm{C}$ for 20 min to unmask antigens. After incubation with the blocking reagent (Nacalai tesque, Japan) for $20 \mathrm{~min}$, sections were incubated with primary antibodies overnight at $4^{\circ} \mathrm{C}$. The anti-phospho-Smad2 antibody and anti-phosphorylated histone 3 antibody were purchased from Cell Signaling (Beverly, MA) and Upstate (Lake Placid, NY), respectively. Unimmuned rabbit IgG was used as a negative control. Immunoreactivity was visualized by ABC kit (Vector Laboratories, USA) with $0.04 \% \mathrm{NiCl}_{2}$. Cultured otic vesicles were fixed for $30 \mathrm{~min}$ in $4 \%(\mathrm{w} / \mathrm{v})$ paraformaldehyde at room temperature. Mouse anti-Tuj1 mAb (Covance, Berkeley, CA, USA) was diluted at 1:1000 with blocking solution. Alexa 568-conjugated goat anti-mouse antibody (Molecular Probes, USA) was used at 1:200. Stained samples were embedded in OCT compound and sectioned at $8 \mu \mathrm{m}$. Microphotographs were taken on AxioPlan (Zeiss, Germany) or VB-7010 (Keyence, Japan). Adobe Photoshop was used to process the photographs.

\section{Semi-quantitative RT-PCR}

Otic vesicles with surrounding mesenchyme were dissected out from embryos at E10.5. They were treated in $1 \mathrm{unit} / \mathrm{ml}$ dispase for 10 minutes at $37^{\circ} \mathrm{C}$. After rinsing in PBS briefly, the surrounding mesenchyme was removed from otic vesicles. Hearts were also dissected out as a positive control. RNA from otic vesicles or heart tissues was isolated using TRIZOL (Invitrogen, Tokyo, Japan). The first strand complementary DNA (cDNA) was synthesized with random primers by Superscript First-Strand Synthesis System (Invitrogen, Tokyo, Japan). PCR was performed with HotStarTaq (QIAGEN, Tokyo, Japan). PCR conditions were: $30 \mathrm{sec}$ at $94^{\circ} \mathrm{C}, 30 \mathrm{sec}$ at $58^{\circ} \mathrm{C}$ and 1 min at $72^{\circ} \mathrm{C}$ for 27,30 or 33 cycles. Products were electrophoresed on $1.5 \%$ agarose gel. Primers were as follows: For TGF $\beta$ typel receptor (511bp product),

Forward: 5'-GCCATAACCGCACTGTCA-3',

Reverse: 5'-ATGGGCAATAGCTGGTTTTC-3';

For TGF $\beta$ typell receptor (437bp product),

Forward: 5'-CCCGGGGCATCGCTCATCTC-3',

Reverse: 5'-AATTTCTGGGCGCCCTCGGTCTCT-3';

For Slug (166bp product),

Forward: 5'-CCAAGGATCACAGTGGTTCA-3',

Reverse: 5'-CAGTGCAGCTGCTTGTGTTT-3'

\section{Organ culture of otic vesicles}

Otic vesicles were dissected out as described above. CVGs which had already developed were removed and then vesicles were transferred into four-well plates (NUNC, Roskilde, Denmark). They were incubated at $37^{\circ} \mathrm{C}$ in a water-saturated atmosphere containing $5 \% \mathrm{CO}_{2}$ (Leon et al., 1995). The standard culture medium consisted of M199 medium with Earle's salts (Gibco, Tokyo, Japan) supplemented with $2 \mathrm{mM}$ glutamine (Nacalai tesque,
Kyoto, Japan), $1 \%$ antibiotic-antimycotic ( 10,000 units/ml penicillinG, 10,000 $\mu \mathrm{g} / \mathrm{ml}$ streptomycin and $25 \mu \mathrm{g} / \mathrm{ml}$ amphotericinB; Gibco, Tokyo, Japan) and $0.1 \%$ BSA (Wako, Tokyo, Japan). Recombinant human TGF $\beta 2$ protein (Peprotech EC Ltd, London, UK) was added in culture at $10 \mathrm{ng} / \mathrm{ml}$. The TGF $\beta$ inhibitor, SB431542, was purchased from Tocris Cookson Ltd (Bristol, UK) and dissolved at a concentration of $10 \mathrm{mM}$ in DMSO as a 2000 $x$ stock solution. As SB431542 was dissolved in DMSO, 0.05\% DMSO was used as a negative control in each experiment.

\section{Statistical analysis of otic vesicle and CVG areas}

Areas of otic vesicles or CVGs were measured on their photomicrographs using Adobe Photoshop and NIH Image. Mann-Whitney U-test was used to assess significance of the data. For Table 1,2 2 Chi square test and Fisher's test was used.

\section{Acknowledgements}

We thank Dr. Moses for Tgf 32 probe, Dr. R. Kageyama for $\mathrm{Ngn} 1$ and NeuroD probes, Dr. Y. Bessho for technical assistance and Drs. T. Miura, S. Yamada and T. Okano for helpful discussion and comments. Also we thank Dr. Murray S. R. Smith for critical reading of the manuscript. This study was supported by The Japanese Ministry of Education, Culture, Sports, Science and Technology (Grant number 15689004, 16015264, 15066201) and Kato Memorial Bioscience Foundation.

\section{References}

ABDOLLAH, S., MACIAS-SILVA, M., TSUKAZAKI, T., HAYASHI, H., ATTISANO, L. and WRANA, J.L. (1997) TbetaRI phosphorylation of Smad2 on Ser465 and Ser467 is required for Smad2-Smad4 complex formation and signaling. $J$ Biol Chem 272: 27678-85.

ALSINA, B., ABELLO, G., ULLOA, E., HENRIQUE, D., PUJADES, C. and GIRALDEZ, F. (2004) FGF signaling is required for determination of otic neuroblasts in the chick embryo. Dev Biol 267: 119-34.

ALVAREZ, Y., ALONSO, M.T., VENDRELL, V., ZELARAYAN, L.C., CHAMERO, P., THEIL, T., BOSL, M.R., KATO, S., MACONOCHIE, M., RIETHMACHER, D. and SCHIMMANG, T. (2003) Requirements for FGF3 and FGF10 during inner ear formation. Development 130: 6329-38.

BIANCHI, L.M., CONOVER, J.C., FRITZSCH, B., DECHIARA, T., LINDSAY, R.M. and YANCOPOULOS, G.D. (1996) Degeneration of vestibular neurons in late embryogenesis of both heterozygous and homozygous BDNF null mutant mice. Development 122: 1965-73.

BLOTTNER, D., WOLF, N., LACHMUND, A., FLANDERS, K. C., UNSICKER, K. (1996)TGF-beta rescues target-deprived preganglionic sympathetic neurons in the spinal cord. Eur J Neurosci 8: 202-10

BRIGANDE, J.V., KIERNAN, A.E., GAO, X., ITEN, L.E. and FEKETE, D.M. (2000) Molecular genetics of pattern formation in the inner ear: do compartment boundaries play a role? Proc Nat/ Acad Sci USA 97: 11700-6.

CAMARERO, G., AVENDANO, C., FERNANDEZ-MORENO, C., VILLAR, A., CONTRERAS, J., DE PABLO, F., PICHEL, J.G. and VARELA-NIETO, I. (2001) Delayed inner ear maturation and neuronal loss in postnatal Igf-1-deficient mice. J Neurosci 21: 7630-41.

CAMARERO, G., LEON, Y., GOROSPE, I., DE PABLO, F., ALSINA, B., GIRALDEZ, F. and VARELA-NIETO, I. (2003) Insulin-like growth factor 1 is required for survival of transit-amplifying neuroblasts and differentiation of otic neurons. Dev Bio/ 262 : 242-53.

CAMARERO, G., VILLAR, M.A., CONTRERAS, J., FERNANDEZ-MORENO, C PICHEL, J.G., AVENDANO, C. and VARELA-NIETO, I. (2002) Cochlear abnormalities in insulin-like growth factor-1 mouse mutants. Hear Res 170: 2-11.

CAMENISCH, T.D., MOLIN, D.G., PERSON, A., RUNYAN, R.B., GITTENBERGERDE GROOT, A.C., MCDONALD, J.A. and KLEWER, S.E. (2002) Temporal and distinct TGFbeta ligand requirements during mouse and avian endocardial cushion morphogenesis. Dev Biol 248: 170-81.

CARNEY, P.R. and SILVER, J. (1983) Studies on cell migration and axon guidance in the developing distal auditory system of the mouse. J Comp Neuro/ 215: 35969. 
CAU, E., GRADWOHL, G., FODE, C. and GUILLEMOT, F. (1997) Mash1 activates a cascade of bHLH regulators in olfactory neuron progenitors. Development 124: 1611-21.

CHAI, Y., ITO, Y. and HAN, J. (2003) TGF-beta signaling and its functional significance in regulating the fate of cranial neural crest cells. Crit Rev Oral Biol Med 14: 78-88.

D'AMICO-MARTEL, A. (1982) Temporal patterns of neurogenesis in avian cranial sensory and autonomic ganglia. Am J Anat 163: 351-72.

DE CAESTECKER, M.P., PARKS, W.T., FRANK, C.J., CASTAGNINO, P., BOTTARO, D.P., ROBERTS, A.B. and LECHLEIDER, R.J. (1998) Smad2 transduces common signals from receptor serine-threonine and tyrosine kinases. Genes Dev 12: 1587-92.

DEL BARRIO, M.G. and NIETO, M.A. (2002) Overexpression of Snail family members highlights their ability to promote chick neural crest formation. Deve/opment 129: 1583-93.

ERNFORS, P., VAN DE WATER, T., LORING, J. and JAENISCH, R. (1995) Complementary roles of BDNF and NT-3 in vestibular and auditory development. Neuron 14: 1153-64.

FARINAS, I., JONES, K. R., BACKUS, C., WANG, X. Y., REICHARDT, L. F. (1994) Severe sensory and sympathetic deficits in mice lacking neurotrophin-3. Nature 369: 658-61

FARKAS, L.M., DUNKER, N., ROUSSA, E., UNSICKER, K. and KRIEGLSTEIN, K. (2003) Transforming growth factor-beta(s) are essential for the development of midbrain dopaminergic neurons in vitro and in vivo. J Neurosci 23: 5178-86.

FEKETE, D.M. and WU, D.K. (2002) Revisiting cell fate specification in the inner ear. Curr Opin Neurobiol 12: 35-42.

FLANDERS, K. C., LUDECKE, G., ENGELS, S., CISSEL, D. S., ROBERTS, A. B., KONDAIAH, P., LAFYATIS, R., SPORN, M. B., UNSICKER, K. (1991) Localization and actions of transforming growth factor-beta $s$ in the embryonic nervous system. Development 113: 183-91

FRENZ, D.A., GALINOVIC-SCHWARTZ, V., LIU, W., FLANDERS, K.C. and VAN DE WATER, T.R. (1992) Transforming growth factor beta 1 is an epithelialderived signal peptide that influences otic capsule formation. Dev Bio/ 153: 32436.

FRITZSCH, B. (2003) Development of inner ear afferent connections: forming primary neurons and connecting them to the developing sensory epithelia. Brain Res Bull 60: 423-33.

HANSEN, M.R., VIJAPURKAR, U., KOLAND, J.G. and GREEN, S.H. (2001) Reciprocal signaling between spiral ganglion neurons and Schwann cells involves neuregulin and neurotrophins. Hear Res 161: 87-98.

HELDIN, C.H., MIYAZONO, K. and TEN DIJKE, P. (1997) TGF-beta signalling from cell membrane to nucleus through SMAD proteins. Nature 390: 465-71.

HEMOND, S.G. and MOREST, D.K. (1991) Ganglion formation from the otic placode and the otic crest in the chick embryo: mitosis, migration and the basal lamina. Anat Embryol (Berl) 184: 1-13.

HOSSAIN, W.A. and MOREST, D.K. (2000) Fibroblast growth factors (FGF-1, FGF2) promote migration and neurite growth of mouse cochlear ganglion cells in vitro: immunohistochemistry and antibody perturbation. JNeurosci Res 62: 4055.

ISHII, Y., FUKUDA, K., SAIGA, H., MATSUSHITA, S. and YASUGI, S. (1997) Early specification of intestinal epithelium in the chicken embryo: a study on the localization and regulation of CdxA expression. Dev Growth Differ 39: 643-53.

JONES, K.R., FARINAS, I., BACKUS, C. and REICHARDT, L.F. (1994) Targeted disruption of the BDNF gene perturbs brain and sensory neuron development but not motor neuron development. Cel/ 76: 989-99.

JOHNSON, M. D., JENNINGS, M. T., GOLD, L. I., MOSES, H. L. (1993) Transforming growth factor-beta in neural embryogenesis and neoplasia. Hum Patho/ 24: 457-62

KIM, W.Y., FRITZSCH, B., SERLS, A., BAKEL, L.A., HUANG, E.J., REICHARDT, L.F., BARTH, D.S. and LEE, J.E. (2001) NeuroD-null mice are deaf due to a severe loss of the inner ear sensory neurons during development. Development 128: $417-26$

KRIEGLSTEIN, K., STRELAU, J., SCHOBER, A., SULLIVAN, A. and UNSICKER, K. (2002) TGF-beta and the regulation of neuron survival and death. J Physio/ Paris 96: 25-30.
LAWOKO-KERALI, G., RIVOLTA, M.N., LAWLOR, P., CACCIABUE-RIVOLTA, D.I., LANGTON-HEWER, C., VAN DOORNINCK, J.H. and HOLLEY, M.C. (2004) GATA3 and NeuroD distinguish auditory and vestibular neurons during development of the mammalian inner ear. Mech Dev 121: 287-99.

LEE, J.E., HOLLENBERG, S.M., SNIDER, L., TURNER, D.L., LIPNICK, N. and WEINTRAUB, H. (1995) Conversion of Xenopus ectoderm into neurons by NeuroD, a basic helix-loop-helix protein. Science 268: 836-44.

LEON, Y., VAZQUEZ, E., SANZ, C., VEGA, J. A., MATO, J. M., GIRALDEZ, F., REPRESA, J., VARELA-NIETO, I. (1995) Insulin-like growth factor-I regulates cell proliferation in the developing inner ear, activating glycosylphosphatidylinositol hydrolysis and Fos expression. Endocrinonlogy 136: 3494-503

LIU, M., PEREIRA, F.A., PRICE, S.D., CHU, M.J., SHOPE, C., HIMES, D., EATOCK, R.A., BROWNELL, W.E., LYSAKOWSKI, A. and TSAI, M.J. (2000) Essential role of BETA2/NeuroD1 in development of the vestibular and auditory systems. Genes Dev 14: 2839-54.

MA, Q., CHEN, Z., DEL BARCO BARRANTES, I., DE LA POMPA, J.L. and ANDERSON, D.J. (1998) neurogenin1 is essential for the determination of neuronal precursors for proximal cranial sensory ganglia. Neuron 20: 469-82.

MARIANO, J. M., MONTUENGA, L. M., PRENTICE, M. A., CUTTITTA, F. JAKOWLEW, S. B. (1998) Concurrent and distinct transcription and translation of transforming growth factor-beta type I and type II receptors in rodent embryogenesis. Int J Dev Biol 42: 1125-36

MARTINOU, J.C., LE VAN THAI, A., VALETTE, A. and WEBER, M.J. (1990) Transforming growth factor beta 1 is a potent survival factor for rat embryo motoneurons in culture. Brain Res Dev Brain Res 52: 175-81.

MASSAGUE, J. (1998) TGF-beta signal transduction. Annu Rev Biochem 67: 75391

MASSAGUE, J. and WOTTON, D. (2000) Transcriptional control by the TGF-beta/ Smad signaling system. EMBOJ 19: 1745-54.

MCFARLANE, S. and COOPER, E. (1993) Extrinsic factors influence the expression of voltage-gated $\mathrm{K}$ currents on neonatal rat sympathetic neurons. $J$ Neurosci 13: 2591-600.

MIETTINEN, P.J., EBNER, R., LOPEZ, A.R. and DERYNCK, R. (1994) TGF-beta induced transdifferentiation of mammary epithelial cells to mesenchymal cells: involvement of type I receptors. J Cel/ Biol 127: 2021-36.

MILLAN, F.A., DENHEZ, F., KONDAIAH, P. and AKHURST, R.J. (1991) Embryonic gene expression patterns of TGF beta 1 , beta 2 and beta 3 suggest different developmental functions in vivo. Development 111: 131-43.

MORSLI, H., CHOO, D., RYAN, A., JOHNSON, R. and WU, D.K. (1998) Development of the mouse inner ear and origin of its sensory organs. J Neurosci 18: 3327-35.

NAKAO, A., AFRAKHTE, M., MOREN, A., NAKAYAMA, T., CHRISTIAN, J.L., HEUCHEL, R., ITOH, S., KAWABATA, M., HELDIN, N.E., HELDIN, C.H. and TEN DIJKE, P. (1997) Identification of Smad7, a TGFbeta-inducible antagonist of TGF-beta signalling. Nature 389: 631-5.

PELTON, R.W., DICKINSON, M.E., MOSES, H.L., HOGAN, B.L., MILLER, D.A and NOMURA, S. (1990) In situ hybridization analysis of TGF beta 3 RNA expression during mouse development: comparative studies with TGF beta 1 and beta 2. Development 110: 609-20.

POULSEN, K.T., ARMANINI, M.P., KLEIN, R.D., HYNES, M.A., PHILLIPS, H.S and ROSENTHAL, A. (1994) TGF beta 2 and TGF beta 3 are potent survival factors for midbrain dopaminergic neurons. Neuron 13: 1245-52.

RAFT S, NOWOTSCHIN S, LIAO J, MORROW BE. (2004) Suppression of neural fate and control of inner ear morphogenesis by Tbx1. Development 131: 180112

ROMANO, L.A. and RUNYAN, R.B. (2000) Slug is an essential target of TGFbeta2 signaling in the developing chicken heart. Dev Biol 223: 91-102.

ROMANO LA, RUNYAN RB (1999) Slug is a mediator of epithelial-mesenchymal cell transformation in the developing chicken heart. Dev Biol. 212: 243-54.

ROSSANT, J., TAM, PPL (2002) Mouse Development. Development of the Mouse Inner Ear, pp. 539-565.

RUBEL, E.W. and FRITZSCH, B. (2002) Auditory system development: primary auditory neurons and their targets. Annu Rev Neurosci 25: 51-101. 
SANFORD, L.P., ORMSBY, I., GITTENBERGER-DE GROOT, A.C., SARIOLA, H., FRIEDMAN, R., BOIVIN, G.P., CARDELL, E.L. and DOETSCHMAN, T. (1997) TGFbeta2 knockout mice have multiple developmental defects that are nonoverlapping with other TGFbeta knockout phenotypes. Development 124: 2659-70.

SCHMID, P., COX, D., BILBE, G., MAIER, R. and MCMASTER, G.K. (1991) Differential expression of TGF beta 1, beta 2 and beta 3 genes during mouse embryogenesis. Development 111: 117-30.

SEFTON, M., SANCHEZ, S. and NIETO, M.A. (1998) Conserved and divergent roles for members of the Snail family of transcription factors in the chick and mouse embryo. Development 125: 3111-21.

SOMETANI, A., KATAOKA, H., NITTA, A., FUKUMITSU, H., NOMOTO, H. and FURUKAWA, S. (2001) Transforming growth factor-beta1 enhances expression of brain-derived neurotrophic factor and its receptor, TrkB, in neurons cultured from rat cerebral cortex. J Neurosci Res 66: 369-76.

SOMETANI A, NOMOTO H, NITTA A, FURUKAWA Y, FURUKAWA S. (2002) 4Methylcatechol stimulates phosphorylation of Trk family neurotrophin receptors and MAP kinases in cultured rat cortical neurons. J Neurosci Res. 70: 335-9.

SOUCHELNYTSKYI, S., TAMAKI, K., ENGSTROM, U., WERNSTEDT, C., TEN DIJKE, P. and HELDIN, C.H. (1997) Phosphorylation of Ser465 and Ser467 in the $C$ terminus of Smad2 mediates interaction with Smad4 and is required for transforming growth factor-beta signaling. J Biol Chem 272: 28107-15.
SPORN, M.B., ROBERTS, A.B., WAKEFIELD, L.M. and DE CROMBRUGGHE, B. (1987) Some recent advances in the chemistry and biology of transforming growth factor-beta. J Cell Biol 105: 1039-45.

SUN, D., VANDERBURG, C.R., ODIERNA, G.S. and HAY, E.D. (1998) TGFbeta3 promotes transformation of chicken palate medial edge epithelium to mesenchyme in vitro. Development 125: 95-105.

SUN, Y., NADAL-VICENS, M., MISONO, S., LIN, M.Z., ZUBIAGA, A., HUA, X., FAN, G., GREENBERG, M.E. (2001) Neurogenin Promotes Neurogenesis and Inhibits Glial Differentiation by Independent Mechanisms. Cel/ 104: 365-376

WILKINSON, D.G. (1992) In situ hybridization; a practical approach, Whole-mount in situ hybridization of vertebrate embryos., pp. 75-84.

WU, D.K. and OH, S.H. (1996) Sensory organ generation in the chick inner ear. $J$ Neurosci 16: 6454-62

Received: September 2004 Reviewed by Referees: November 2004 Modified by Authors and Accepted for Publication: January 2005 